\title{
Between Resistance and Adaptation
}

The Place of the Uyghur Language in the Sinicised Zone of Ürümchi

\section{Giulia Cabras}

\section{(2) OpenEdition}

\section{Journals}

Electronic version

URL: http://journals.openedition.org/chinaperspectives/7475

ISSN: 1996-4617

\section{Publisher}

Centre d'étude français sur la Chine contemporaine

\section{Printed version}

Date of publication: 1 December 2017

Number of pages: 41-48

ISSN: 2070-3449

\section{Electronic reference}

Giulia Cabras, « Between Resistance and Adaptation », China Perspectives [Online], 2017/4 | 2017,

Online since 01 December 2018, connection on 28 October 2019. URL : http://

journals.openedition.org/chinaperspectives/7475

This text was automatically generated on 28 October 2019 .

(c) All rights reserved 


\section{Between Resistance and Adaptation}

The Place of the Uyghur Language in the Sinicised Zone of Ürümchi

\section{Giulia Cabras}

\section{ABSTRACTS}

The urban areas of Xinjiang have recently experienced major changes in their demographic, urban, ethnic, and linguistic landscapes. Ürümchi, the capital of the Xinjiang Uyghur Autonomous Region, is a typical example of this. In this city, which is undergoing rapid economic and urban expansion, the Han make up around $72 \%$ of the population and the Chinese language is ever more present in the language use of the Uyghurs. This study examines the place of the Uyghur language in the context of the sinicisation of the city of Ürüchi, its role in the daily life of the Uyghur community, and opportunities for its use and revitalisation.

\section{INDEX}

Keywords: Ürümchi, Uyghur community, Uyghur language, language use, language policies

\section{AUTHOR}

\section{GIULIA CABRAS}

Giulia Cabras has a Ph.D. in language sciences from the Institut National des Langues et Civilisations Orientales, Paris. She is currently a post-doctoral researcher at Freie University.Freie Universität, Kaiserswerther Str. 16-18, 14195 Berlin, Germany (giulia.cabras@inalco.fr). 